\title{
Modern problems of ecological education and culture in the society development
}

\author{
Lyubov Krutova ${ }^{1, *}$ \\ ${ }^{1}$ Moscow Technological Institute, 199334, Moscow, Russia
}

\begin{abstract}
High rate of technical progress is the driving force of society development and its adverse consequences pose new challenges in the field of environmental economics that require the special attention, quick decisions and maximum efficiency. Currently worldwide there is an acute problem of waste disposal, energy conservation and efficiency, low environmental education of the population. Disposal and waste recycling, for example, is costly. To reduce significantly these costs could have some improvements such as separate waste collection at the Institute, introduction of energy efficiency programs and conducting lectures, seminars and master classes.
\end{abstract}

\section{Introduction}

Ten years passed from the moment of UNO's (United Nations Organisation) announcement "Education's decade for...sustainable development" (2005-2014 years). Education for sustainable development is a dynamic concept that includes all aspects of society awareness, education and training in order to ensure or increase understanding of the relationship between sustainable development and development of knowledges, skills, perspectives and values which will enable people of any age to assume certain responsibilities for creating sustainable future and the possessing of them.

Announcing of decade appeared in response to awakening by the world community that traditional contents, firms and methods of education already are not capable of providing new generation of young people to life in globalization world where traditional economics of closest interests tears up the foundations of Life on the Earth each moment. According to Tatyana Akimova, doctor of science, Economics peoples' friendship university of Russia, globalization can accept humanitarian orientation only realizing sustainable development's conception [1].

There are structural changes in the world now. First, this is the increase of resource efficiency, for example energy-saving technologies. Secondly, in different countries there is a real revolution in the energy field and create a fuel for various engines, including, for public and private transport (for example, Chinese development by hydrogen fuel's train). And, finally, entering the economy of the closed cycle, when waste is recycled for production as raw material.

On the current stage of the society development the ecological education and its promotion in the society, among businessmen, politics, etc., is becoming more and more actual. Knowing and understanding the ecological issues, the importance to address them on all the levels of social life are integral part on the mankind's existence. Developed market economies have begun teaching youth on the sustainability and caring about the nature and its treasures since people are the major element that links economy and ecology. People's activity is the source and the reason of interrelated ecological and economic crises in various regions of the planet. The contradiction between economy and ecology comes up because of certain attitude of people towards the world around them. People try to adjust potential of the environment to their own needs. Since the deformational changes in this ratio are growing because the ecology is exhausted being affected by social development, there is an urgent need to foster social consciousness and responsibility as well as create ecological and economical mindset.

Today one can witness a growth of people's understanding and awareness of importance of developing serious attitude towards environment. As a result, there are founded multiple ecological organizations. It becomes very popular to be ecologically conscious, consume eco-friendly products, life in green zones, protect wild nature, provide stricter sanctions against those who violate the ecological laws and pollute the environment.

According to authors [8], social consciousness and responsibility when it touches on the environmental issues as well as creating ecological and economical mindset is on the top of the must-do list of education. To resolve the problems, which the modern society is facing in the areas of sustainable business and protecting the environment, it needs to develop all forms and types of ecological education.

\footnotetext{
Corresponding author: 1 krutova@mti.edu.ru
} 
There are some modern lacks of environmental students' education:

- insufficient realization the idea of "greening" education in practice, such as the insufficient using the ecological potential of different disciplines' contents;

- little attention was paid to addressing specific local and regional environmental issues, what and how you can change in your everyday life to reduce anthropogenic pressure on the environment and environmental risk to humans;

- lack of system diagnostics and self-diagnostics level of formation the ecological students' competence.

Another serious problem of all big cities is the waste management [7].

In most developed countries, the solution to this problem is based on a system of recycling. Literally "recycling" means "return to circulation". Recycling is not just the use of waste as secondary raw materials, it is the basis of a systematic approach to the problem of rational use of resources.

In the United States since 1976 there is the law "About conservation of resources and their recovery" (Resource Conservation and Recovery) [10], which determines standards for the solid waste disposal. The standards regulate the landfills that accept municipal waste, and a mandatory minimum recycled content in commercial products.

The organization of new landfills is prohibited by law in the USA. But burning waste according to compliance with all environmental regulations is more expensive than recycling into secondary raw materials. Many States have laws under which each County under threat of funding termination from the state is obliged by a certain date to enter the re-cyclization of some portion of waste on its territory. Everywhere the dumping of car batteries is prohibited.

The recycling act(Krw-/AbfG) is valid also in Germany. It was adopted in 1996 [11]. This law is especially effective in the field of automobiles recycling The basic idea is to require manufacturers reduce the amount of future waste in the development stage of products.

This experience is highly relevant for Russian cities, especially for Moscow, because the problem of domestic and industrial waste disposal is extremely serious. Now the main method of disposal is the disposal of waste on special landfills in the Moscow region, which is actually a huge garbage dump and is a powerful source of environmental pollution. In addition, many of the landfills will run their life in the near future. Currently, waste incineration is the only alternative to landfills. But their construction was problematic in the City. It becomes evident the need to urgently develop a state program aimed at the introduction of household and industrial waste recycling in our country. Such a system would reduce the amount of waste destined for disposal, and at the same time would contribute to the conservation of valuable resources.

\section{Methods}

Sustainable development is closely linked to the processes of modernization and ecologization of the economy, and this requires not just investment in the environment or new technologies, but social innovations, changing priorities and goals of civilization development [5]. The transition to an innovation way of sustainable development is the primary strategic incentive for improving energy efficiency for our State. According to the long-term socially and economic development Concept of the Russian Federation for the period up to 2020, the global economy feature such as improving energy efficiency and increasing the role of environmental factors will have the significant impact on the development of our country in the next $10-15$ years [9]. A special role will be given to reducing of the energy consumption, the creating of innovative and technological bases for the formation of a "green" economy, characterized by low level of negative impact on the environment.

Green economy is the concept of the new economy, involving the welfare of the population and reducing risks to the environment [3].

The "green" economy often means only "green" business, covering the production of various types of cleaning equipment, utilization of secondary resources and waste, providing environmental services and so on. In this case, a green economy is only a part of the "great" economy. Obviously the "peaceful" coexistence of "green" and natural-resourced "brown" economy is hardly possible. For example, the trends' conservation of energy and metallurgy for the extensive development with the rapid development of "green" business will lead to the saving the raw materials export and unsustainable economy for Russia. Thus "green" transformation should cover the entire economy, and the process of greening can be really effective at the macro level only. In the transition Strategy of the European community to "green" economy by 2050 this economy is identified with a system that combines the ecosystem (natural capital), the economy (physical capital) and society (human capital) (fig. 1, towards a green economy in Europe. EU environmental policy targets and objectives 2010-2050. European Environment Agency, Copenhagen, 2013).

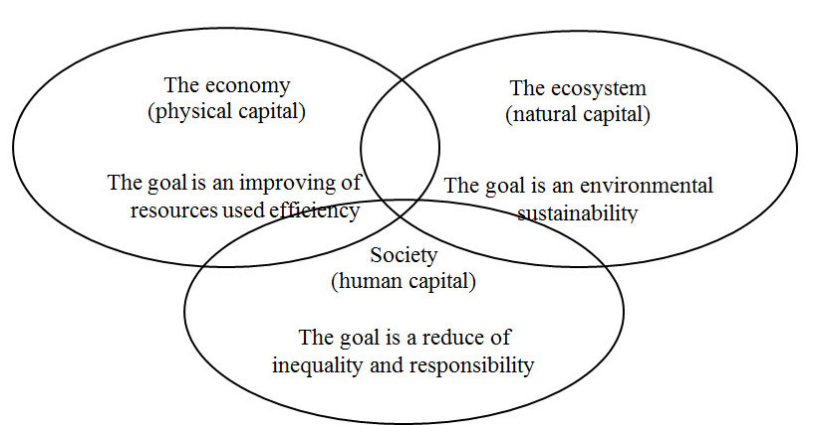

Fig 1. The structure of Green economy

Green technology is the most important tool for the industries' development, affecting the economic security of the country and the quality of people's life. It is the 
construction sector, energy sector, transport, industry, waste management, organic foods' production. Of course, the industry is constantly overlap, so the experts of "green" technologies are referred to as cross-cutting development tool.

Higher education institutions can contribute to the development of this process because traditionally, all over the World at universities in some of the environmental initiatives and future environmental leaders can emerge [6].

Despite of positive reasons, which should facilitate the transition to green economy in Russia, there are some barriers of this process, such as [4]:

- the lack of sufficient political interest to implement the "green" economy technologies, for example, to increase the share of alternative sources in the energy balance, recycling, introduction of best available technologies;

- the inertia of the economic model transformation (from export-raw to innovative), as well as lack of capacity or desire to change the situation in the business environment;

- low actuality of environmental issues in the minds of decision makers, low involvement in the constructive population's ecological activism.

As the experience of developed and developing States these barriers can be overcome. Higher education institutions can play a significant role in overcoming these barriers and the formation of the "green" economy.

Let's consider the development of introduction of "green technologies" concept into the work of the

University. The aim is an increasing the competitiveness of the University and formation of green economy on local level in the implementation of specific technologies in higher education, for example, separate collection of municipal solid waste (MSW) for further processing.

The novelty consists in the creation of the complex development program of green University as a pilot site for the implementation of "green" technologies in

our life, uniting scientists, teachers, students, and administrative services.

The objectives of this concept are:

1) implementation of the project in the University;

2) creation of conditions for separate collection of waste;

3) interaction with external organizations;

3) undertaking environmental education activities;

4) maintaining, increasing and restoring of the natural capital;

5) prevent the loss of ecosystem services;

6) savings of the University budget.

The implementation of this concept will require the following key issues:

1. The analysis of the modern institutional support in the field of waste management, such as removal of obstacles to the system organization of collection and removal household wastes and insufficient stimulation of recycling
1.1. The formation of a team leaders to create conditions for separate waste collection in the University.

1.2. Informing students and employees.

1.3. Interaction with external organizations.

1.4. Organizing and conducting environmental, events, seminars, attracting students.

1.5. The analysis of the General economic situation with the collection of recyclable materials.

2. Development, promotion and implementation of energy-saving technologies.

2.1. Save heat.

2.1.1. Technology of heat substations' modernization.

2.1.2. Thermal management.

2.2. Organization of resource and energy savings.

2.3. The establishment of a working group on the implementation of the energy management system.

2.4. Company's energy policy.

2.5. Planning.

2.5.1. The energy profile of the enterprise.

2.5.2. Using of basic energy.

2.5.3. Indicators of energy efficiency.

2.5.4. Legal and other requirements.

2.5.5. Goals, objectives and action plan.

2.6. Implementation and operation.

2.6.1. Competence, training, awareness.

2.6.2. Operational control.

2.6.3. The exchange of information.

2.6.4. Development projects.

2.8. Performance review.

2.8.1. Monitoring, measurement and analysis. improving.

2.8.2. Discrepancies, amendments, warnings and

2.8.3. Control statements.

2.9. Environmentally responsible procurement in the sphere of public catering.

3. Environmental education in High school.

3.1. Open seminars, master-classes by Russian experts and foreign scientists.

3.2. Urban environmental Summer Schools for pupils and students.

3.3. The scientific conference.

3.4. The project "Green Future University".

\section{Conclusions}

The Department of green economy will allow to solve the following tasks:

1)preparation of master courses at the economic faculty in the direction of green economy and sustainable development;

2)prepare master program in Bioeconomy on the economic faculty;

3)implementation of the research project "technology of open government for sustainable development";

4)the introduction of education principles for sustainable development and improving energy efficiency, organization of separate garbage collection; 
5)create a platform for interaction between science, business, society and authorities on the topic of green economy and sustainable energy.

The creation of such centers on the bases of Russian universities and their cooperation with foreign universities can bring a positive result. All of this is necessary to promote a green economy and transition to sustainable development in Russia through research and education, research and expert support in conjunction with the development of young people's design skills.

Economic education for sustainable development is a step to reforming the education's system and information politics on the base of new scientific paradigm. All of this extends a subject of economic theory and practice largely. As a result of studying of economic subjects must become the knowledges about new strategies of development, about economics, which can bring scales and character of the household activities as consisted with ecological durability of nature and necessary quality of habitat. In the frame of such a comprehension and according to new world-view, ESD ought to be understood as the main direction of economic theory, studying human behavior in conditions of social and ecological limitations.

\section{References}

1. T.A. Akimova, Osnovy ekonomiki ustoychivogo razvitiya (Moscow, Economika Publ., 2013)
2. I.V. Babanin, Tverdie bytovie othody, 3, 56-60 (2009)

3. S.N. Bobylev, V.M. Zaharov, Obshhestvennoj palaty RF, 60 (2012)

4. P.A. Kirushin, M.A. Strygina, E.S. Kashirina, Vest. Mosk. un. Ser. 6. Ekonomika, 5, 72 (2015)

5. L.S. Krutova, Ekonomika I predprinimatelstvo, 12, 228 (2015)

6. C.A. Lipina, Sovremennie proizvoditelnie sily, 2, 138-144 (2015)

7. K.V. Papenov, S.M. Nikonorov, O.V. Zemskova Problemy prognozirovaniya, 5, 119-126 (2015)

8. L.V. Starchenko, V.V. Lukyanenko, In Energy effectiveness of economics and ecological security: theory and practice: Proceedings of the 11th International conference of Russian society of ecological economics (Moscow, 2011)

9. http://www.economy.gov.ru/

10. http://www.epa.gov/epawaste/lawsregs/rcrahistory.htm

11. http://www.quickiwiki.com/de/Kreislaufwirtschafts gesetz 